\title{
Development of novel composite fire-extinguishing powders on the basis of mineral raw materials
}

\author{
L. Gurchumelia, G. Baliashvili, F. Bejanov \& N. Sarjveldze \\ G. Tsulukidze Mining Institute, Tbilisi, Georgia
}

\begin{abstract}
The aim of the presented investigation is the elaboration of non-halogen, nontoxic, ecologically sound, high-efficient, universal, composite fire extinguishing powders on the basis of domestic mineral raw materials which satisfy the following requirements:

- are characterized with high performance properties and fire extinguishing ability;

- $\quad$ are used for extinguishing of all classes of fires;

- $\quad$ are used for extinguishing of large-scale fires, forest fires and at the same time provide the enrichment of burnt out soils with different necessary salts;

- are used in large temperature range, as well as at such low temperatures when $\mathrm{CO}_{2}$, water and foam cannot be used;

- at extinguishing will make heterogenic as well as homogeneous inhibition of burning process.
\end{abstract}

Keywords: non-halogen, non-toxic, ecologically sound, composite fire extinguishing powders, performance properties, fire extinguishing ability, thermogravimetric analysis.

\section{Introduction}

Since those early days, millions of dollars have been spent on campaigns to prevent forest fires. But the result is not always sufficient. Forest fires are one of the most dangerous natural phenomena, leading to considerable economic losses and ecologic effects. They initiate long-lasting changes of all components of landscape and change microclimate conditions of atmosphere on the surface of the 
ground. Thus, fire damage is alarming: plants and animals are ruined, soil is polluted and sometimes population is poisoned or chocked by emitted gases, $[1,2]$.

Therefore, before the whole world there arises the problem of fire localization, suppression and development of such safety precautions which will provide inhibition of burning of matter in the zone of inflammation and decrease of toxic materials emission at thermal destruction. The most effective of these measures is the use of fire extinguishing measures. The most effective fireextinguishing measures are powder fire extinguishers which practically can be used to extinguish all classes of fires. They act even at such low temperatures when Freon, $\mathrm{CO}_{2}$, water and foam cannot be used, [5-7].

But it should also be mentioned that serial production powders are rather expensive and cannot satisfy the modern demands, in the first place with the viewpoint of effective and universal using. Most of them are halogen containing. It is unambiguously stated that when halogen gets into atmosphere it causes the disturbance of ozone layer. Therefore, at present one of the most important problems is the elaboration of halogen-free, nontoxic, ecologically pure, inexpensive fire extinguishing powders, $[5,6,8]$.

With consideration of the above said in our work we describe the ways of development of halogen-free, ecologically pure, high efficiency, cheap, universal, composite fire-extinguishing powders on local mineral material.

The local mineral raw material - clay shale and zeolite - are taken as the basis for receiving such powders. At destruction at high temperatures of the mentioned minerals the emission of asphyxiating gases and toxic matters does not happen. To some extent, zeolites act as fertilizers and after fire enrich the soil with different necessary mineral salts.

The minerals are selected according to their high performance properties and fire extinguishing capacity.

The condition of powder dispersion degree was chosen so that particle sizes were satisfactory for their quick heating and destruction, i.e. there should happen homogeneous action of combustion products on flame, as well as heterogenic inhibition of burning process.

\section{Experimental procedure}

Minerals are chosen according to their high performance properties and considering the effectiveness which indicate the reduction of burning processes. This is enabled with the results of chemical and thermogravimetric analysis of minerals.

Mineralogical composition of shist group clay shales, crystalline zeolites clinoptilolites, presented in table 1 , show that they mainly contain alkali and alkaline-earth metal carbonates, bicarbonates, oxalates, silicates, Fe, $\mathrm{Al}$ and alkali metal hydroxides, crystallization water. Therefore, at high temperatures these minerals are characterized with emission of uninflammable gases, water steam and metal oxides which dilute combustible products, creating protective film and coke layer on the surface of material. The investigation and estimation of these processes are done with thermogravimetric analysis. 
Table 1: $\quad$ Chemical containing of minerals.

\begin{tabular}{|c|c|c|c|c|c|c|c|c|c|c|c|}
\hline \multirow{2}{*}{ Materials } & \multicolumn{10}{|c|}{ Main components (\%) } \\
\cline { 2 - 12 } & $\mathrm{S}_{1} \mathrm{O}_{2}$ & $\mathrm{Al}_{2} \mathrm{O}_{3}$ & $\mathrm{Fe}_{2} \mathrm{O}_{3}$ & $\mathrm{FeO}$ & $\mathrm{CaO}$ & $\mathrm{MgO}$ & $\mathrm{CO}_{2}$ & $\mathrm{SO}_{3}$ & $\mathrm{Na}_{2} \mathrm{O}$ & $\mathrm{K}_{2} \mathrm{O}$ & $\mathrm{H}_{2} \mathrm{O}$ \\
\hline $\begin{array}{c}\text { Clay } \\
\text { shale }\end{array}$ & 51.2 & 13.6 & 7.40 & - & 8.06 & 3.02 & 10.62 & 0.9 & 3.02 & 2.1 & - \\
\hline Zeolite & 62.9 & 14.45 & 2.32 & 0.51 & 5.67 & 1.32 & - & - & 3.73 & 0.42 & 2.16 \\
\hline
\end{tabular}

The thermogravimetric measurements were performed using a derivatograph of Paulic, Paulic \& Erdey (Hungary). Experimental data is given on fig.1, 2.

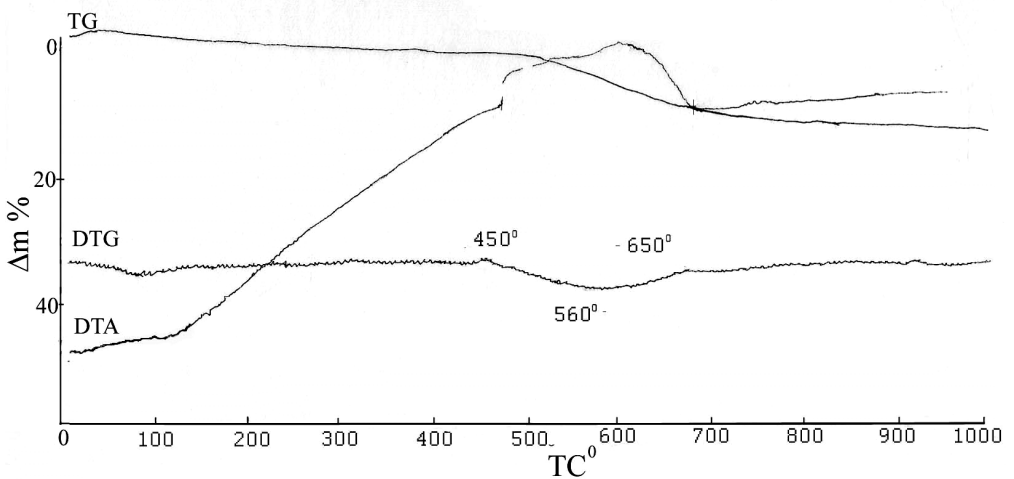

Figure 1: Derivatogram of clay shale.

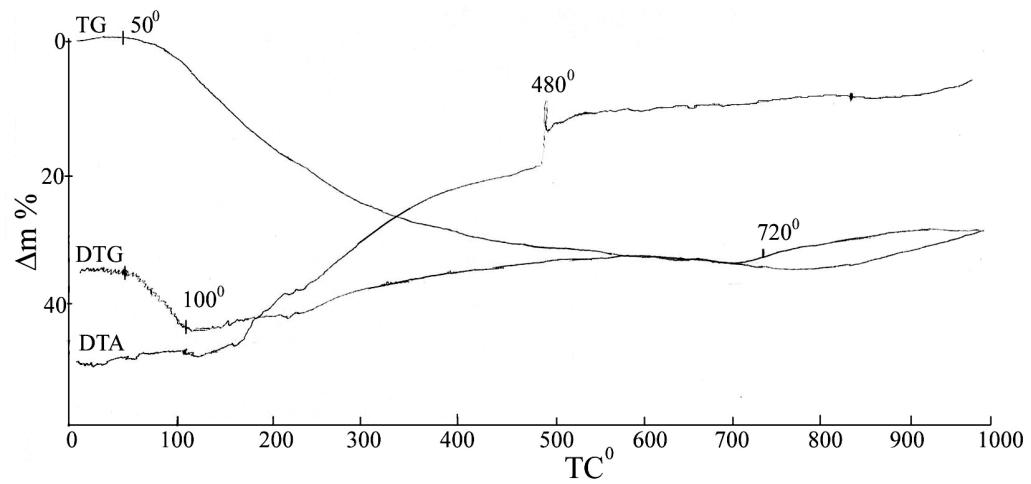

Figure 2: Derivatogram of zeolite.

\subsection{Performance properties}

In order to study performance properties of powders laboratory methods [9] are used: 
- powder dispersivity, $x(\%)$ - granulometric composition, mass concentration of powder remains left on the sieve

$$
x=\frac{m_{1}}{m}
$$

where: $m_{1}$ - mass of powder remains on the sieve, $\mathrm{kg}$;

$m$ - total mass of remains, $\mathrm{kg}$.

- powder fluidity, $Q(\mathrm{~kg} / \mathrm{s})$ - powder mass consumption in time necessary for its dispersion from test fire extinguisher

$$
Q=\frac{m-m_{\tau}}{\tau}
$$

where: $m$ - mass of extinguisher before testing, $\mathrm{kg}$;

$m_{\tau}$ - mass of extinguisher after testing, $\mathrm{kg}$.

- moisture content and tendency to humidity, $W(\%)$ - the ratio of moist absorbed with powder to powder mass

$$
W=\frac{m_{1}-m}{m} \cdot 100
$$

where: $m_{1}$ - mass of powder remains after moisting, $\mathrm{kg}$;

$m$ - total mass of remains, $\mathrm{kg}$.

- tendency to consolidation and caking, $C(\%)$ - caked mass ratio to powder mass:

$$
C=\frac{m_{c}}{m}
$$

where: $m_{\mathrm{c}}$ - mass of formed cakes, $\mathrm{kg}$;

$m$ - powder mass, $\mathrm{kg}$.

Test data of performance factors of clay shales and zeolites are given in table 2. Table data show that zeolites are characterized with low tendency to

\begin{tabular}{|c|c|c|c|c|c|}
\hline & Materials & $\begin{array}{l}\text { Granulometric } \\
\text { composition, } \\
\text { mass } \\
\text { concentration of } \\
\text { powder remains } \\
\text { left on the sieve }\end{array}$ & $\begin{array}{l}\text { Powder } \\
\text { fluidity, } \\
\text { Q (kg/s) }\end{array}$ & $\begin{array}{c}\text { Moisture } \\
\text { content and } \\
\text { tendency to } \\
\text { humidity, } \\
\text { W (\%) }\end{array}$ & $\begin{array}{c}\text { Tendency to } \\
\text { consolidation } \\
\text { and caking, } \mathrm{C} \\
(\%)\end{array}$ \\
\hline \multirow{2}{*}{1} & \multirow{2}{*}{ Clay Shale } & № $0.25-80$ & \multirow{2}{*}{0.17} & \multirow{2}{*}{1.02} & \multirow{2}{*}{2.03} \\
\hline & & № $0.50-6$ & & & \\
\hline \multirow{2}{*}{2} & \multirow{2}{*}{$\begin{array}{l}\text { Zeolite } \\
\text { (Clinoptilolite) }\end{array}$} & № $0.25-85$ & \multirow{2}{*}{0.15} & \multirow{2}{*}{7.7} & \multirow{2}{*}{0.8} \\
\hline & & № $0.50-5$ & & & \\
\hline \multirow{2}{*}{3} & Clay Shale & № $0.25-80$ & \multirow{2}{*}{0.14} & \multirow{2}{*}{5.6} & \multirow{2}{*}{1.2} \\
\hline & Zeolite & № $0.50-50$ & & & \\
\hline
\end{tabular}
consolidation and caking but with high capacity of moisture absorption which considerably decreases at admixture of clay shales.

Table 2: $\quad$ Performance properties. 


\subsection{Fire extinguishing ability}

With consideration of standard conditions of development of different type fires the fire extinguishing ability of powders is determined with experimental (polygon) method which allows to define: a) minimum quantity of powder which is consumed for fire extinguishing or minimum consumption per unit area $(\mathrm{G})$ and $b$ ) time of fire extinguishing $(\tau)$.

Experiment results for clay shales and zeolites are given in table 3.

Table 3: $\quad$ Fire-extinguishing ability.

\begin{tabular}{|c|c|c|c|c|c|c|}
\hline \multirow[b]{2}{*}{ Material } & \multicolumn{4}{|c|}{ Seat of fire } & \multirow[b]{2}{*}{$\begin{array}{c}\text { Time of fire } \\
\text { extinguishing, } \\
\tau(\mathrm{s})\end{array}$} & \multirow[b]{2}{*}{$\begin{array}{c}\text { Minimum } \\
\text { consumption } \\
\text { per unit area, } \\
\mathrm{G}\left(\mathrm{kg} / \mathrm{m}^{2}\right)\end{array}$} \\
\hline & $\begin{array}{l}\text { Class } \\
\text { of fire }\end{array}$ & $\begin{array}{l}\text { Length } \\
\text { of seat } \\
\text { of fire, } \\
\mathrm{L}(\mathrm{m})\end{array}$ & $\begin{array}{c}\text { Area of } \\
\text { extinguishing, } \\
\mathrm{S}\left(\mathrm{m}^{2}\right)\end{array}$ & $\begin{array}{c}\text { Volume } \\
\text { of fuel, } \\
\text { V (1) }\end{array}$ & & \\
\hline \multirow{2}{*}{ Clay shale } & A & 0.5 & 0.9 & - & 12 & 2.3 \\
\hline & B & - & 0.25 & 4 & 10 & 6.8 \\
\hline \multirow{2}{*}{$\begin{array}{c}\text { Zeolite } \\
\text { (Clinoptil } \\
\text { olite) }\end{array}$} & A & 0.5 & 0.9 & - & 8 & 1.15 \\
\hline & B & - & 0.25 & 4 & 7 & 3.6 \\
\hline \multirow{2}{*}{$\begin{array}{c}\text { Zeolite }+ \\
\text { Clay shale }\end{array}$} & A & 0.5 & 0.9 & - & 10 & 1.5 \\
\hline & B & - & 0.25 & 4 & 8 & 4.4 \\
\hline
\end{tabular}

Test results show that zeolites are characterized with higher fire extinguishing ability than clay shales. Admixture of zeolites with clay shales considerably increases fire extinguishing abilities.

\section{Results and discussion}

On the basis of thermogravimetric analysis of clay shales and zeolites, it is stated that their destruction goes on by stages.

Zeolite destruction begins at considerably low temperature than that of clay shales. Endothermic effect is noted in temperature range of $50-480^{\circ} \mathrm{C}$ (with maximum $\mathrm{t}=100^{\circ} \mathrm{C}$ ). Peak profile on DTG curve indicates the coincidence of some endoeffects. It is supposed that at first adsorption water is separated and water containing silicates are dehydrated, then crystallization water and hydroxyl groups are removed (dehydroxylization), which is resulting in mineral amorphization (mass loss 11-15\%).

In temperature interval of $480-700^{\circ} \mathrm{C}$ zeolites are somehow stable, do not undergo structural changes, which is proved by the growth of adsorption properties of gases. Therefore, in this interval mass loss is gradually decreased, 
while above $700^{\circ} \mathrm{C}$ because of gases adsorption mass begins to increase. On DTA curve the process is accompanied with exothermic effect which continues to the end of recording - to $1000^{\circ} \mathrm{C}$. At this stage there happen simultaneous decomposition and oxidation process. Presumably there happens decomposition of hydrocarbonates and hydroxides and further oxidation of oxides received by decomposition, burning out of admixtures.

For clay shales the loss of adsorbed water is not noticed. Their destruction begins at relatively high temperature $-120-130^{\circ} \mathrm{C}$. At the first stage, in temperature interval of $130-450^{\circ} \mathrm{C}$ mass losses are insignificant, unimportant endo- and exoeffects are noticed which supposedly correspond to crystallization water separation and decarbonization. At $450^{\circ} \mathrm{C}$ shale amorphization takes place similarly to that of zeolite, while for clay shales in $450-800^{\circ} \mathrm{C}$ temperature interval mass loss increases, in the same on DTA curve there is noticed an exoeffect which continues from $450^{\circ} \mathrm{C}$ to $700^{\circ} \mathrm{C}$. Peak profile on DTG curve indicates coincidence of some endoeffects. It is supposed that at first crystallization water is separated, hydrocarbonates, bicarbonates and variable valency metal hydroxides are decomposed and then admixtures are burnt out and iron oxides recovered.

Proceeding from the above said, at high temperatures above $800^{\circ} \mathrm{C}$ for zeolites, as well as, clay shales it is characteristic to create protective film and coke layer of variable valency metal oxides on material surface. At this time material begins to soften, near the surface closed pores are formed which prevent the separation of gases and material begins to rise.

Thus, emanated uninflammable gases and water steam in flame zone act as phlegmatizers while in surface zone they cause the formation of risen layer. The risen layer, metal oxides protective film and coke layer create the "fire restricting" effect.

\section{Conclusions}

This study has shown that composite fire-extinguishing powders based on domestic mineral raw materials (zeolites and clay shales) are characterized with high performance properties and fire-extinguishing ability, are non-halogen, nontoxic, ecologically sound, high-efficient and act as fertilizers after fire, enriching the soil with different minerals.

It is supposed that these powders may be used for extinguishing of large-scale fires, forest fires and in large temperature range, as well as at such low temperatures when $\mathrm{CO}_{2}$, water and foam cannot be used.

\section{References}

[1] Forest Fires. Environmental Literacy Council Web Site, Washington, DC, http://www.enviroliteracy.org/article.php/46.html

[2] INDEPTH: FORCES OF NATURE; Forest Fires. The Canadian Broadcasting Centre Web Site, Toronto, http://www.cbc.ca/news/ background/forcesofnature/forestfires.html 
[3] Selivyorstov, V.I., Zemskova, Yu. V. Automatic Powder Fire extinguishing. Features and problems, Ltd. "Kalancha" Web Site, http://www.kalancha.ru/htm/inven/Powder_world-and-security.htm

[4] Fire extinguishing powder, "Nauka v Sibiri", Weekly Newspaper of Siberian Brunch of the Russian Academy of Sciences, N40 (2276), October 13, 2000. http://www.sbras.ru/HBC/hbc.phtml?9+115+1

[5] Zahabiya Chemical Industries, www.zahabiya.com

[6] Takahashi, F., Linteris, G.T. \& Katta, V. R., Physical and Chemical Aspects of Cup-Burner Flame Extinguishment. Halon Options Technical Working Conference, 15th Proceedings. Next Generation Fire Suppression Technology Program, May 24-26, 2005, Albuquerque, NM, pp. 1-10, 2005.

[7] Baratov, A.N. \& Vogman, L.P., Fire extinguishing powder compositions. Stroyizdat, Moscow, 1982.

[8] Baratov, A.N., Kopylov, N.P. \& Timofeev, E.V., About Substitution for Ozone-Depleting Agents for Fire Extinguishing. Proceedings of the $12^{\text {th }}$ Halon Options Technical Working Conference, eds. R.G Gann \& P.A. Reneke, NIST SP 984: Gaithersburg, MD, pp. 1-12, 2002.

[9] Fire Extinguishing Powders of General Purpose. Testing methods. Normative Documents, НПБ 170-98, Russia, 1998. 